\title{
Perceptions and experiences of cyberbullying amongst university students in the Eastern Cape province, South Africa
}

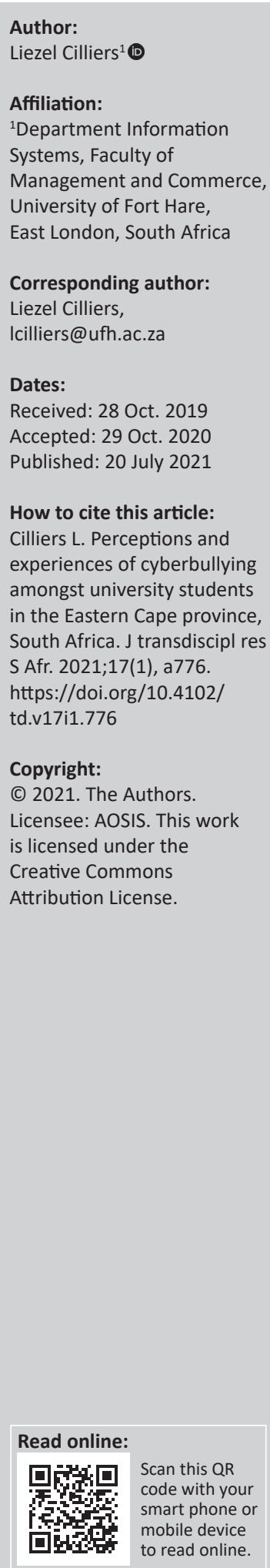

\begin{abstract}
Cyberbullying in South Africa has become a problem in the recent past. However, there is a lack of research focusing on cyberbullying at the university level. This study investigates the perceptions and experiences of cyberbullying amongst tertiary students in the Eastern Cape province. The study used a quantitative survey approach to collect data from 150 students at a university in the Eastern Cape. The results indicated that one-third of the students had been victims of cyberbullying. Overall, students considered cyberbullying as a serious issue, but less than one-third of the students could identify the indirect methods of cyberbullying. The topic has not been incorporated into policy or the university curriculum in South Africa. This study recommends that the Department of Higher Education must provide a standardised policy and curriculum on cyberbullying that universities can use to implement and enforce cyber safety behaviour at the university.
\end{abstract}

Keywords: curriculum; cyberbullying; Eastern Cape higher education; policy; students.

\section{Introduction}

Generation $\mathrm{Z}$ has made social media a fundamental part of their lives. ${ }^{1}$ Mander et al. ${ }^{2}$ found that, on average, Generation Z spends 163 min a day on social networks and messaging sites. This statistic can be attributed to the fact that this generation was the first to have grown up in a world with constant Internet technology and connectivity ${ }^{1}$. Generation $\mathrm{Z}$ is a group of people who were born in the period 1995-2012. The youngsters in this group are comfortable with technology and use various social platforms to socialise with their friends and family. ${ }^{3}$

Social media exposes the user to digital crimes such as identity theft, inappropriate material and cyberbullying. ${ }^{4}$ Cyberbullying is defined as 'any behaviour performed through electronic or digital media by individuals or groups that repeatedly communicates hostile or aggressive messages intended to inflict harm or discomfort on others' (p. 278). ${ }^{5}$ According to the definition, technology must be used to bully, harass or threaten the victim. This type of harassment is very difficult to stop as technology is being used in all parts of our lives, thus creating a power imbalance. ${ }^{6,7}$

Meyers et al. ${ }^{8}$ found that there is an increased interest in cyberbullying in students older than 16 years around the world, in countries such as Canada, Finland, the United States of America and the United Kingdom. These studies found that the impact of cyberbullying may be as severe for the older population as amongst children. The negative effects of cyberbullying include longterm impact on psychosocial development, self-esteem, academic achievement and mental health problems such as depression and social anxiety.

Farhangpour et al. ${ }^{9}$ found that 55\% of learners in Limpopo had experienced some form of cyberbullying in the past, whilst the International Mathematics and Science Study (TIMSS) found that $17 \%$ of Grade 9 students in South Africa reported being exposed to some form of bullying on a weekly basis. ${ }^{10}$ These studies were conducted amongst school learners in South Africa, but less attention has been given to tertiary students in the country. ${ }^{11,12,13}$ Cilliers et al. ${ }^{14}$ reported that $45.5 \%$ of student teachers whom they surveyed had previously been victims of cyberbullying. Young adults and university students, in particular, have increased access to social media, which is now unsupervised as they become independent adults and, thus, the impact of cyberbullying must be investigated within this cohort. ${ }^{13}$ Kraft et al. ${ }^{15}$ reported that being a victim of cyberbullying in high school was a significant risk factor to be cyberbullied at university. This study attempts to fill this gap in the literature. The objective of the study is to investigate the perceptions and 
experiences of cyberbullying amongst tertiary students in the Eastern Cape province.

The rest of the article will discuss the literature that supports cyberbullying in South African universities, followed by the research method that was used to collect data, the analysis and discussion of these results and finally the conclusion.

\section{Literature}

The digital population in South Africa consists of 31.18 million Internet users, of which 28.99 million users access the Internet on their mobile devices. ${ }^{16}$ Generation $\mathrm{Z}$ is considered the excessive users of the Internet as they must have access to technology at all times. When the Internet is not available, they experience 'social phobia' or 'social anxiety disorders' as they fear they may be missing out. Furthermore, excessive use of social media can result in vision defects, impaired academic performance, attention problems, sleep disorders and behavioural problems amongst students. ${ }^{17}$

There are various types of cyberbullying that students can be subjected to in the digital environment. Table 1 provides an overview of the different types of cyberbullying. ${ }^{5,18}$

Valcke et al. ${ }^{19}$ provided the 'five $\mathrm{Cs}^{\prime}$ as a framework for researchers to conceptualise online behaviour and cyberbullying. The first $C$ refers to the context where students spend time online. The social media penetration rate in South Africa is $40 \%$ of the population, with Facebook being the most popular with a penetration rate of $53 \%$ of all users, followed by LinkedIn (18\%), Instagram (9\%), Twitter (4\%) and Snapchat (3\%). Cyberbullying can potentially impact these South African Internet users. ${ }^{16}$ The second C stands for online contacts or social relationships that students have on social media. Students prefer using social media to communicate and interact with friends and family; hence, they belong to at least one social network for this purpose, which makes cyberbullying a relevant issue amongst this group. ${ }^{1}$ The third and fourth Cs refer to how students manage their confidentiality online and their general online conduct, which extends to technical skills and self-regulation. Students

TABLE 1: Types of cyberbullying.

\begin{tabular}{ll}
\hline Type of cyberbullying & Definition \\
\hline Harassment & $\begin{array}{l}\text { Rude, insulting or threatening messages, which attack the } \\
\text { victim's physical or social attributes }\end{array}$ \\
$\begin{array}{l}\text { Offensive, rude and vulgar language to insult and threaten } \\
\text { someone }\end{array}$ & $\begin{array}{l}\text { Messages that are untrue, harmful or even cruel often with } \\
\text { 'evidence' of a digitally altered picture so as to present a } \\
\text { false image of the victim }\end{array}$ \\
$\begin{array}{l}\text { Identity theft or } \\
\text { masquerade }\end{array}$ & $\begin{array}{l}\text { Pretending to be someone else to send abusive messages } \\
\text { Outing }\end{array}$ \\
$\begin{array}{l}\text { Involves posting personal communications/images } \\
\text { containing intimate and potentially embarrassing personal } \\
\text { information }\end{array}$ \\
$\begin{array}{l}\text { Trickery } \\
\text { The victim is tricked into thinking that communication is } \\
\text { threaten to distribute the information }\end{array}$ \\
Exclusion & $\begin{array}{l}\text { Bully decides who is allowed to a member of an online } \\
\text { group by 'unfriending' those not deemed worthy }\end{array}$ \\
Cyberstalking & $\begin{array}{l}\text { Sending repeated messages that threaten to harm, } \\
\text { intimidate or is extremely offensive to the victim }\end{array}$ \\
\hline
\end{tabular}

are sharing more information about themselves on social media sites than they did in the past, but most reported high confidence in their ability to manage their privacy settings, whilst $60 \%$ said that they prefer to keep their Facebook profiles private. However, cyberbullying can occur regardless of these countermeasures, and as the student is connected to the Internet continuously, it becomes very difficult to avoid or stop cyberbullying. ${ }^{20}$ The last $C$ refers to the content that the students are uploading, use and access, which can be used to perpetrate or become the victim of cyberbullying. Social media has become an extension of the identity of the Generation Z users, which makes the impact of cyberbullying much more powerful. ${ }^{21}$ The bully can avoid confrontation as technology provides them with the means to stay anonymous. In addition, cyberbullying is often more aggressive than traditional bullying as the bully does not experience empathy and remorse towards their targets as they are not aware of the consequences of their behaviour. ${ }^{22}$ Cyberbullies are more likely to have lower levels of guilt, shame and remorse when they engage in cyberbullying because of the anonymity that the Internet provides..$^{23,24}$

The amount of time that students spend online, and in particular on social media sites, has been shown to predict the likelihood of being involved in cyberbullying. ${ }^{8}$ Social media, particularly Facebook, is the most common medium used for cyberbullying amongst university students. ${ }^{13}$ Lindsay et al. ${ }^{25}$ also found that owning a smartphone is a risk factor for cyberbullying amongst university students. Additional risk factors include the status of the student, if they belong to a fraternity, political or other influential organisation, relationship difficulties and sexual orientation. ${ }^{8}$ The consequences of cyberbullying amongst students included depression, low self-esteem, poor academic performance and even suicide. Little research has been conducted amongst students about coping strategies to deal with cyberbullying. Some of the coping strategies that have been identified amongst high school students include ignoring or avoiding bullying, doing nothing or retaliation. ${ }^{13}$ Schenk et al. ${ }^{26}$ reported similar results amongst students at an American university, which dealt with cyberbullying by telling someone to avoid friends or take revenge on the bully. Typically, students prefer to speak to peers, then parents and lastly the university staff about cyberbullying. The most popular online coping strategy seems to be 'blocking' the cyberbully and staying away from the social media site where the bullying is taking place whilst offline coping strategy relies on seeking help from friends. These coping strategies point to university students engaging in autonomous and problem-focused coping strategies to deal with cyberbullying. ${ }^{27}$

There is a general lack of awareness and responsiveness about cyberbullying in South Africa. There is no legislation in South Africa that prohibits cyberbullying. ${ }^{24}$ Schools do not include the topic in their curriculum and do not have a policy on how to prevent and deal with cyberbullying., ${ }^{4,28}$ At home, parents have a limited understanding of how their children 
interact with the Internet and are not able to provide adequate education to their children about cyberbullying., ${ }^{4,23}$ Many Internet users do not know where to turn for assistance if they are the victim of cyberbullying. They lack awareness and knowledge of how to protect themselves and their personal information online. Young people do not report cyberbullying because of these problems. The consequences of cyberbullying for the student have been reported in the literature to be low self-esteem, family problems, academic problems, school violence, delinquent behaviour and suicidal thoughts. ${ }^{6,24}$

\section{Research methodology}

This research study employed a positivistic paradigm with a quantitative approach. The study used a survey to collect data from 150 university students aged 19-30 years across all levels of study and the five faculties in the university (see Table 3). The survey was based on the published work from Molluzzo et al., ${ }^{30}$ which compared the perceptions of cyberbullying amongst faculty and students. The instrument was adopted for this study and consisted of 5 sections and 24 items overall. Section A (seven questions) solicited demographic information from respondents, whilst section $B$ (three questions) measured the overall perception of cyberbullying. Section C (four questions) measured the awareness about cyberbullying of the respondents, whilst section D (six questions) measured the perceived severity of cyberbullying. Section E included four questions about the

TABLE 2: Demographic information of respondents.

\begin{tabular}{|c|c|c|c|c|c|c|c|c|c|}
\hline \multicolumn{5}{|l|}{ Variable } & \multicolumn{2}{|l|}{$n$} & \multicolumn{3}{|c|}{$\%$} \\
\hline \multicolumn{10}{|l|}{ Gender } \\
\hline \multicolumn{5}{|l|}{ Female } & \multicolumn{2}{|l|}{86} & \multicolumn{3}{|c|}{57.3} \\
\hline \multicolumn{5}{|l|}{ Male } & \multicolumn{2}{|l|}{64} & \multicolumn{3}{|c|}{42.7} \\
\hline \multicolumn{10}{|c|}{ Level of study } \\
\hline \multicolumn{5}{|c|}{ Undergraduate } & \multicolumn{2}{|l|}{98} & \multicolumn{3}{|c|}{65.3} \\
\hline \multicolumn{5}{|c|}{ Postgraduate } & \multicolumn{2}{|l|}{52} & \multicolumn{3}{|c|}{34.7} \\
\hline \multicolumn{10}{|c|}{ How often do you use social media? } \\
\hline \multicolumn{5}{|c|}{ Several times a day } & \multicolumn{2}{|l|}{114} & \multicolumn{3}{|c|}{76.0} \\
\hline \multicolumn{5}{|c|}{ Once a day } & \multicolumn{2}{|l|}{11} & \multicolumn{3}{|c|}{7.3} \\
\hline \multicolumn{5}{|c|}{ Several times a week } & \multicolumn{2}{|l|}{21} & \multicolumn{3}{|c|}{14.0} \\
\hline \multicolumn{5}{|c|}{ Once a week } & \multicolumn{2}{|l|}{4} & \multicolumn{3}{|c|}{2.7} \\
\hline \multicolumn{10}{|c|}{ Level of experience with social media } \\
\hline Excellent & & & & & 46 & & & 30.7 & \\
\hline Good & & & & & 83 & & & 55.3 & \\
\hline Average & & & & & 20 & & & 13.3 & \\
\hline Poor & & & & & 1 & & & 0.7 & \\
\hline Most popi & arsc & ial med & a site & used & & & & & \\
\hline Facebook & & & & & 77 & & & 51.3 & \\
\hline Twitter & & & & & 12 & & & 8.0 & \\
\hline IMS & & & & & 50 & & & 33.3 & \\
\hline Other & & & & & 11 & & & 7.3 & \\
\hline IMS, Instan & Mess & ge Servi & & & & & & & \\
\hline Variable & Edu & ation & & & $\begin{array}{r}\text { Mana } \\
a \\
\text { comr }\end{array}$ & $\begin{array}{l}\text { ement } \\
\text { dd } \\
\text { lerce }\end{array}$ & $\begin{array}{l}\text { Health } \\
\text { sciences }\end{array}$ & & $\begin{array}{l}\text { cial } \\
\text { nces }\end{array}$ \\
\hline & $n$ & $\%$ & $n$ & $\%$ & $n$ & $\%$ & $\%$ & $n$ & $\%$ \\
\hline Faculty & 48 & 32.0 & 27 & 18.0 & 57 & 38.0 & 8.7 & 5 & 3.3 \\
\hline
\end{tabular}

cyberbullying curriculum and policy issues at the university. Section $\mathrm{F}$ tested the personal experience of the respondents with cyberbullying (two questions). Sections C-F used a four-point Likert scale (where 1 denotes strongly disagree and 4, strongly agree) to test the perceptions of students regarding cyberbullying. Ethical clearance was obtained to conduct the study before the data collection. The questionnaire was randomly distributed to a convenience sample of respondents over 1 week. A total of 150 questionnaires were returned. Statistical analyses were done using SPSS V24. Cronbach's alpha coefficient $(\alpha)$ was used to test for internal consistency of the instrument and found to be 0.730 , which is deemed to be acceptable. ${ }^{31}$

\section{Ethical consideration}

This article followed all ethical standards for carrying out research.

\section{Results}

Descriptive analysis was conducted to examine the perceptions and experiences of cyberbullying amongst university students. Table 2 presents the descriptive data for the study sample of 150 respondents.

Almost two-thirds (65.3\%) of the respondents were undergraduate, which is consistent with the composition of the student population of the university. The majority of the students (83.3\%) indicated that they use social media daily, with Facebook being the most popular social media site (51.3\%). Not surprising for Generation Z students, 86\% indicated that their level of experience with social media is either excellent or good.

The study population consisted of university students who were registered for various degrees across five faculties of a traditional university. Table 3 provides an overview of the composition of the students per faculty.

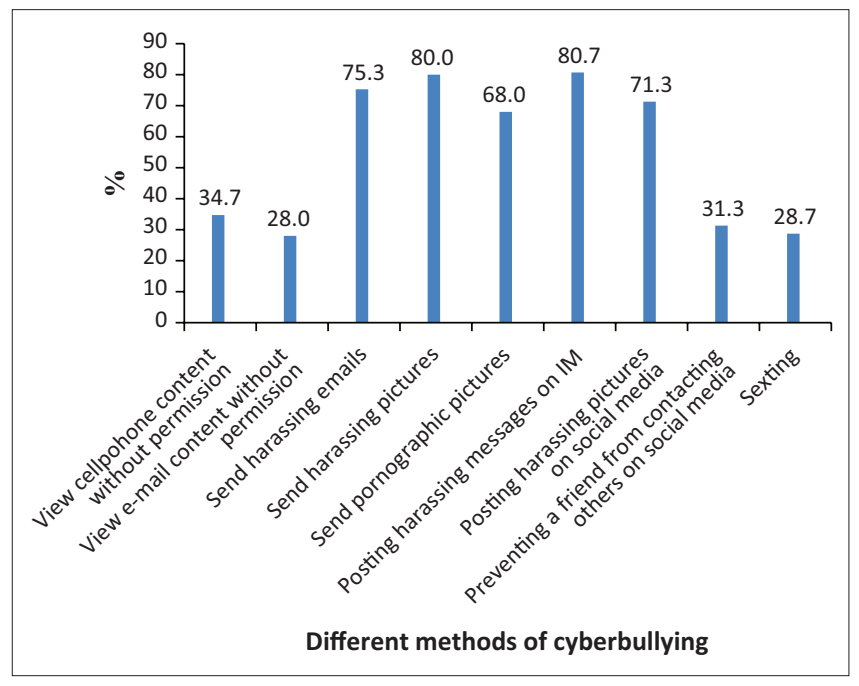

IM, instant messaging.

FIGURE 1: Methods that can be used to cyberbully. 
Figure 1 presents the various methods that can be used to cyberbully an individual. The respondents in the study were asked to indicate which of these methods they considered to be associated with cyberbullying. The most recognised methods were sending or posting harassing messages or pictures on social media or instant messaging (IM). Sexting, exclusion and unauthorised access to emails and mobile phones were recognised as cyberbullying by less than onethird of the respondents.

The respondents were asked whom they would report cyberbullying to if they were the victims of such an act. A small number of students (4.7\%) stated that they would not tell anyone, whilst the majority told they would report it to a councillor at the university $(63.3 \%)$ or the head of the department where they studied (50.7\%). A total of $42 \%$ students stated that they would inform the police whilst $22.7 \%$ said they would inform the parents of the perpetrator.

When asked about what they thought would be an appropriate penalty for cyberbullying, the majority of respondents reported that a warning letter $(63.3 \%)$ or suspension $(65.3 \%)$ would be an appropriate punitive measure, whilst $30.0 \%$ indicated that immediate expulsion was warranted. Only $3.3 \%$ of the respondents indicated that no penalty should be given for cyberbullying.

\section{Awareness}

This category tested the awareness of cyberbullying amongst the respondents in their local schools and in South Africa. The majority of respondents (90.7\%) have heard of cyberbullying, whilst $66 \%$ of respondents were aware of specific cyberbullying that occurred outside the university. A total of $70.0 \%$ of the respondents indicated that they were aware of cyberbullying that happened within the university. Half of the respondents (54.7\%) felt that they were knowledgeable about how the law addresses cyberbullying in South Africa. The results are presented in Table 4.

\section{The seriousness of cyberbullying}

The prevalence of cyberbullying at the university was 36\% amongst this group of respondents, whilst $17.3 \%$ of the respondents admitted that they have engaged in cyberbullying (Table 5). Slightly more respondents stated that cyberbullying was a problem for their friends than for themselves (69.3\% vs. $62.0 \%)$. However, $74.6 \%$ of respondents felt that cyberbullying was a serious issue at the university in general. This is supported by the findings that $88.7 \%$ of the respondents felt that cyberbullying was an invasion of their privacy and $90 \%$ was wrong.

\section{Prevention of cyberbullying}

Cyberbullying was not addressed within the various courses the respondents were registered for, as illustrated by $34 \%$ of respondents who agreed that cyberbullying was discussed in their classes and $73.3 \%$ of respondents who indicated that the topic should be included in the curriculum.

At the university administrative level, only $28.7 \%$ of the respondents stated that they were aware of a cyberbullying policy at the university, whilst $87.4 \%$ felt the university could do more to promote awareness about cyberbullying amongst students (Table 6).

Pearson's correlation coefficient is used to show the relationship or association between two continuous variables. The coefficient provides information about the magnitude and direction of the relationship. ${ }^{31}$ A Pearson's test revealed several significant differences for gender, year of study and which social media site the respondents used:

- Undergraduate students were more aware of cyberbullying than postgraduate students $(r=0.170$; $p<0.05)$.

- Undergraduate students felt that cyberbullying was a serious issue at the university $(r=0.163$; $p<0.05)$.

- Female students indicated that cyberbullying was a serious issue for their friends $(r=0.166 ; p<0.05)$.

TABLE 4: Awareness of cyberbullying among students.

\begin{tabular}{|c|c|c|c|c|c|c|c|c|}
\hline \multirow[t]{2}{*}{ Variable } & \multicolumn{2}{|c|}{ Strongly disagree } & \multicolumn{2}{|c|}{ Disagree } & \multicolumn{2}{|c|}{ Agree } & \multicolumn{2}{|c|}{ Strongly agree } \\
\hline & $n$ & $\%$ & $n$ & $\%$ & $n$ & $\%$ & $n$ & $\%$ \\
\hline I am aware of instances of cyberbullying at the university. & 11 & 7.3 & 34 & 22.7 & 76 & 50.7 & 29 & 19.3 \\
\hline I am aware of cyberbullying as an activity on the Internet. & 4 & 2.7 & 9 & 6.0 & 73 & 48.7 & 63 & 42.0 \\
\hline $\begin{array}{l}\text { I am aware of cyberbullying activities in general (e.g. the Western Cape } \\
\text { learner who committed suicide as a result of cyberbullying). }\end{array}$ & 11 & 7.3 & 40 & 26.7 & 68 & 45.3 & 31 & 20.7 \\
\hline I am knowledgeable of the laws on cyberbullying in South Africa. & 17 & 11.3 & 51 & 34.0 & 66 & 44.0 & 16 & 10.7 \\
\hline
\end{tabular}

TABLE 5: Perception of seriousness of cyberbullying.

\begin{tabular}{|c|c|c|c|c|c|c|c|c|}
\hline \multirow[t]{2}{*}{ Variable } & \multicolumn{2}{|c|}{ Strongly disagree } & \multicolumn{2}{|c|}{ Disagree } & \multicolumn{2}{|c|}{ Agree } & \multicolumn{2}{|c|}{ Strongly agree } \\
\hline & $n$ & $\%$ & $n$ & $\%$ & $n$ & $\%$ & $n$ & $\%$ \\
\hline Cyberbullying is a serious issue for me. & 15 & 10.0 & 42 & 28.0 & 60 & 40.0 & 33 & 22.0 \\
\hline Cyberbullying is a serious issue for my friends. & 9 & 6.0 & 37 & 24.7 & 75 & 50.0 & 29 & 19.3 \\
\hline Cyberbullying is a serious issue at the university in general. & 8 & 5.3 & 28 & 18.7 & 74 & 49.3 & 38 & 25.3 \\
\hline Cyberbullying is a violation of privacy, regardless of the intent of the perpetrator. & 8 & 5.3 & 9 & 6.0 & 66 & 44.0 & 67 & 44.7 \\
\hline Cyberbullying, pure and simple, is wrong. & 6 & 4.0 & 8 & 5.3 & 45 & 30.0 & 90 & 60.0 \\
\hline
\end{tabular}




\begin{tabular}{|c|c|c|c|c|c|c|c|c|}
\hline \multirow[t]{2}{*}{ Variable } & \multicolumn{2}{|c|}{ Strongly disagree } & \multicolumn{2}{|c|}{ Disagree } & \multicolumn{2}{|c|}{ Agree } & \multicolumn{2}{|c|}{ Strongly agree } \\
\hline & $n$ & $\%$ & $n$ & $\%$ & $n$ & $\%$ & $n$ & $\%$ \\
\hline Issues of cyberbullying have been discussed in your classes at the university & 48 & 32.0 & 51 & 34.0 & 41 & 27.3 & 10 & 6.7 \\
\hline I think that cyberbullying should be included in the curriculum at university. & 13 & 8.7 & 27 & 18.0 & 71 & 47.3 & 39 & 26.0 \\
\hline I am aware of the cyberbullying policy of the university. & 29 & 19.3 & 78 & 52.0 & 31 & 20.7 & 12 & 8.0 \\
\hline The university should do more to promote the cyberbullying awareness amongst students. & 5 & 3.3 & 14 & 9.3 & 61 & 40.7 & 70 & 46.7 \\
\hline $\begin{array}{l}\text { The university should sponsor seminars or training for staff and students on the problems } \\
\text { of cyberbullying as an activity harmful to learners. }\end{array}$ & 5 & 3.3 & 18 & 12.0 & 70 & 46.7 & 57 & 38.0 \\
\hline
\end{tabular}

- Students who used Facebook felt that cyberbullying was a serious issue at the university $(r=0.061$; $p<0.05)$.

\section{Discussion}

This study investigated the perceptions and experiences of cyberbullying amongst tertiary students in the Eastern Cape. Cyberbullying is a prevalent issue, with most of the respondents $(70.0 \%)$ indicating that they are knowledgeable about the issue. More female respondents felt that cyberbullying was a serious issue. Punyanunt-Carter ${ }^{32}$ reported that female students are more likely than their male counterparts to report cyberbullying as they have more relational interactions online and disclose more personal information online.

More than one-third of the respondents (36.0\%) indicated that they had previously been victims of cyberbullying themselves. This is in line with the results of studies conducted by De Lange et al., ${ }^{4}$ which reported a prevalence of $36 \%$ of cyberbullying amongst school learners in South Africa, and Kokkinos et al., ${ }^{13}$ which reported that cyberbullying in higher education can range between 10\% and $35 \%$. Of concern was that $17.3 \%$ of the respondents stated that they had previously been perpetrators of cyberbullying. Meyer et al. $^{8}$ reported that there is a continuation of cyberbullying from high school to university level, with about half of bullies and victims reporting that they were already perpetrators or victims of cyberbullying at school. Bullies may view their behaviour as acceptable and 'normal' and as there are less accountability and consequences for their actions from parents or university management, the behaviour may escalate. It is thus no surprise that the majority of respondents $(74.6 \%)$ stated that cyberbullying was a serious issue at the university.

The coping mechanisms of the respondents were mostly to inform authority figures, such as the head of department or counsellor on the campus, of cyberbullying attempts. Only a small proportion of respondents $(4.7 \%)$ would not tell anyone that they were cyberbullied. Meyer et al. ${ }^{8}$ found that university counselling services should play an important role to combat cyberbullying. The personnel should be aware of the seriousness of cyberbullying and provide screening tools to identify psychological issues, such as depression or anxiety, for students who report cyberbullying. Authority figures at the university level should be familiar with strategies to mitigate cyberbullying, such as blocking and reporting mechanisms.
Most of the respondents identified direct cyberbullying behaviours, such as harassment of someone making use of pictures on Facebook or harmful messages on instant messaging. However, very few respondents recognised indirect cyberbullying behaviour, such as unauthorised access to their email or cellphone, exclusion from social media or sexting as cyberbullying. Indirect cyberbullying behaviour is tended to damage the reputation of the victim, interfere with relationships or exclude the victim from social media sites. ${ }^{13}$

To address cyberbullying at the university level, $73.3 \%$ of the respondents felt that the topic should be included in the curriculum of the various degrees, whilst $87.4 \%$ wanted the university to do more to promote awareness regarding the topic. This is probably because only one-third of the respondents $(34 \%)$ were taught about cyberbullying in their classes. ${ }^{29}$ The university does not have a cyberbullying policy, which makes it surprising that $28 \%$ of the respondents indicated that they were familiar with such a policy. The respondents most likely confused the policy on the use of the information and communications technology (ICT) infrastructure of the university with a policy that is dedicated to cyberbullying. South Africa does not have any specific legal avenues for victims of cyberbullying to pursue and instead rely on the National Cyber Security Policy Framework for South Africa, the Child Protection Act and proposed Cybercrimes and Cybersecurity Bill. Meyers et al. ${ }^{8}$ reported that this is a global problem as many universities across the world lack policies on cyberbullying, whilst many countries do not recognise cyberbullying as a crime.

\section{Conclusion}

This study investigated the perceptions and experiences of cyberbullying amongst tertiary students in the Eastern Cape province, South Africa. Cyberbullying has become an essential issue as Generation Z, representing students at university, has more access to technology and is connected to the Internet all the time. However, not much has been done at national or university level to protect the students from the negative consequences of cyberbullying. The study found that students felt that cyberbullying was a serious issue, with one-third of the students being victims of cyberbullying. Most students could identify direct cyberbullying methods, but lack insight into indirect cyberbullying. The most popular coping mechanism for cyberbullying was to report the matter to a councillor or the head of the department at the university. Cyberbullying was included in the curriculum at the university but only in one-third of the classes. However, most students 
indicated that the university should do more to address cyberbullying, using curriculum content or policy. The limitations of the study are that the findings from populations at one university may not be generalised without caution. Cyberbullying is a sensitive issue that needs to be addressed with caution, but more insight regarding the topic could be collected through interviews. This study collected data only through a survey that may not be enough to address the in-depth knowledge required for the topic. Future opportunities for research in this area are essential because of the limited knowledge about cyberbullying in the university setting.

\section{Acknowledgements Competing interests}

The author has declared that no competing interest exists.

\section{Author's contributions}

I declare that I am the sole author of this research article.

\section{Funding information}

This research received no specific grant from any funding agency in the public, commercial or not-for-profit sectors.

\section{Data availability statement}

Data sharing is not applicable to this article as no new data were created or analysed in this study.

\section{Disclaimer}

The views and opinions expressed in this article are those of the author and do not necessarily reflect the official policy or position of any affiliated agency of the author.

\section{References}

1. Prakash Yadav G. \& Rai J. The generation $Z$ and their social media usage: A review and a research outline. Glob J Enterp Inf Syst. 2017;9(2):110-116. https://doi. org/10.18311/gjeis/2017/15748

2. Mander J, Young K. Gen z: Examining the attitudes and digital behaviors of internet users aged 16-20 [homepage on the Internet]. 2017 [cited 2017 Oct 23]. Available from: https://cdn2.hubspot.net/hubfs/304927/Downloads/GenZ-SummaryReport-Q2-2017.pdf

3. Pringle H. Spotting the difference between a baby boomer and generation z- and why it matters for marketers [homepage on the Internet]. The Drum 2015 [cited 2017 Oct 23]. Available from: http://www.thedrum.com/opinion/2015/08/03/ spotting-difference-between-babyboomer-and-generation-z-and-why-it-matters

4. De Lange M, Von Solms R. An e-Safety educational framework in South Africa. Southern Africa Telecoms and Network Applications Conference (SATNAC), George; 2012.

5. Tokunaga RS. Following you from home: A critical review and synthesis of research on cyberbullying victimisation. Comput Hum Behav. 2010;26(3):277-287. https:// doi.org/10.1016/j.chb.2009.11.014

6. Goodno NH. How public schools can constitutionally halt cyberbullying: A model cyberbullying policy that considers first amendment, due process, and fourth amendment challenges. Wake Forest Law Rev. 2011;46:641-700.

7. Kowalski RM, Limber SP. Psychological, physical, and academic correlates of cyberbullying and traditional bullying. J Adolesc Health. 2013;53(1):S13-S20. https://doi.org/10.1016/j.jadohealth.2012.09.018
8. Meyers CA, Cowie H. Bullying at university: The social and legal contexts of cyberbullying among university students. J Cross Cult Psychol. 2017:48(8): 1172-1182. https://doi.org/10.1177/0022022116684208

9. Farhangpour P, Maluleke C, Mutshaeni HN. Emotional and academic effects of cyberbullying on students in a rural high school in the Limpopo province, South Africa. S Afr J Inf Manag. 2019;21(1):a925. https://doi.org/10.4102/sajim. v21i1.925

10. Mullis IVS, Martin MO, Foy P, Hooper M. TIMSS 2015 international results in mathematics [homepage on the Internet]. Chestnut Hill, MA: TIMSS \& PIRLS International Study Center, Boston College; 2016 [cited 2019 June 30]. Available from: http://timssandpirls.bc.edu/timss2015/international-results/wp-content/ uploads/filebase/full\%20pdfs/T15-International-Results-in-Mathematics.pdf

11. Kowalski R, Giumetti G, Schroeder A, Lattanner M. Bullying in the digital age: A critical review and meta-analysis of cyberbullying research among youth. Psychol Bull. 2014;140(4):1073-1137. https://doi.org/10.1037/a0035618

12. Schenk AM, Fremouw WJ. Prevalence, psychological impact, and coping of cyberbully victims among college students. J Sch Violence. 2012;11(1):21-37. https://doi.org/10.1080/15388220.2011.630310

13. Kokkinos CM, Antoniadou N, Markos A. Cyber-bullying: An investigation of the psychological profile of university student participants. J Appl Dev Psychol. 2014;35(3):204-214. https://doi.org/10.1016/j.appdev.2014.04.001

14. Cilliers $L$, Chinyamurindi W. Perceptions of cyberbullying in primary and secondary schools amongst student teachers in the Eastern Cape province of South Africa. EDJIS. 2019;32(1):1-19. https://doi.org/10.18489/sacj.v32i1.737

15. Kraft EM, Wang J. An exploratory study of the cyberbullying and cyberstalking experiences and factors related to the victimisation of students at a public liberal arts college. Int J Technoethics. 2010;1(4):74-91. https://doi.org/10.4018/jte. 2010100106

16. BusinessTech. These are the biggest social media and chat platforms in [homepage on the Internet]. 2019 [cited 2019 June 30]. Available from: https://businesstech. co.za/news/internet/296752/these-are-the-biggest-social-media-and-chatco.za/news/internet/
platforms-in-2019/

17. World Health Organization. World health statistics 2016: Monitoring Health for the SDGs [homepage on the Internet]. Publications of the WHO. 2016 [cited 2017 Oct 25]. Available from: http://www.who.int/gho/publications/world_health statistics/2016/EN_WHS2016_OC.pdf

18. Rachoene M, Oyedemi T. From self-expression to social aggression: Cyberbullying culture among South African youth on Facebook. Comms. 2015;41(3):302-319. https://doi.org/10.1080/02500167.2015.1093325

19. Valcke $M$, De Wever B, Van Keer H, Schellens T. A long-term study of safe internet use of young children. Comput Educ. 2011;57(1):1292-1305. https://doi. org/10.1016/j.compedu.2011.01.010

20. Madden $M$, Lenhart $A$, Cortesi $S$, et al. Teens, social media, and privacy. 2013;21(1055):2-86.

21. Hang WS, Foo LCY, Kang MWT, Wong SY. The impact of social media (YouTube) towards the behavioral change of Generation Z [Doctoral dissertation]. Malaysia: Universiti Tunku Abdul Rahman; 2018.

22. Unisa, Bureau of Market Research. Age inappropriate viewing and online victimisation among South African youth [homepage on the Internet]. 2011 [cited 2013 July 17]. Available from: http://www.unisa.ac.za/contents/faculties/ems/ docs/FINAL_2011_05406.pdf

23. Cross D, Barnes A, Hearn L, Lester L. A social-ecological framework for understanding and reducing cyberbullying behaviours. Aggress Violent Behav. 2015;23:109-117. http://doi.org/10.1016/j.avb.2015.05.016

24. Smit DM. Cyberbullying in South African and American schools: A legal comparative study. S Afr J Educ. 2015;35(2):1076. https://doi.org/10.15700/saje. v35n2a1076

25. Lindsay M, Krysik J. Online harassment among college students. Inf Commun Soc. 2012;15(5):703-719. https://doi.org/10.1080/1369118X.2012.674959

26. Schenk AM, Fremouw WJ, Keelan CM. Characteristics of college cyberbullies. Comput Hum Behav. 2013;29(6):2320-2327. https://doi.org/10.1016/j.chb.2013. 05.013

27. Zimmer-Gembeck MJ, Skinner EA. The development of coping across childhood and adolescence: An integrative review and critique of research. Int J Behav Dev. 2011;35(1):1-17. https://doi.org/10.1177/0165025416653483

28. Govender I, Skea B. Teachers' understanding of E-safety: An exploratory case in KZN South Africa. Electron J Inf Syst Dev Ctries. 2015;70(1):1-17. https://doi. org/10.1002/j.1681-4835.2015.tb00505.x

29. Kritzinger E. Short-term initiatives for enhancing cyber-safety within South African schools. S Afr Comput J. 2016;28(1):1-17. https://doi.org/10.18489/sacj. v28i1.369

30. Molluzzo JC, Lawler JP. A comparison of faculty and students perceptions of cyberbullying. J Inf Syst Educ. 2014;12(2):47-63.

31. Pallant J. A step by step guide to data analysis using IBM SPSS. Sydney: Allen \& Unwin; 2013.

32. Punyanunt-Carter N. An analysis of college students' self-disclosure behaviours on the internet. Coll Stud J. 2006;40:329-331. 